\title{
Manufacturing Enterprise Executive Career Expectation and Enterprise Risk: Theoretical Path and Empirical Evidence
}

\author{
Yi Yao \\ School of Financial Management, Chongqing College of Electronic Engineering, Chongqing, China
}

\begin{abstract}
This paper takes listed companies in Shanghai and Shenzhen stock markets as research samples to analyze and test the relationship between executive career expectation and enterprise risk. This paper argues that manufacturing enterprise executive career expectations have a dual impact on corporate risk, one is to increase corporate risk through investment effect, the other is to reduce corporate risk through reputation effect. The results show that, in the two effects, reputation effect plays a leading role, that is, the higher the career expectation of executives, the more attention they pay to the professional reputation they try to build. In order to protect their own reputation from damage, executives pay more attention to the risk management and internal control of enterprises, so as to reduce the risk of enterprises. This also shows that reputation has a "implicit" incentive effect on executives .This study provides a theoretical basis for enterprises to formulate "explicit" and "implicit" incentive contracts.
\end{abstract}

Keywords: Manufacturing Enterprise, Executive career expectation, investment effect, reputation effect, enterprise risk

\section{Introduction}

The international situation, economic environment and political environment are increasingly complex. In the process of production and operation, enterprises are faced with more and more risks, such as operation risk, control risk and financial risk. In such a big environment, the factors affecting enterprise risk and the research related to enterprise risk have gradually become one of the important issues concerned by the theoretical and practical circles. According to the existing research, the various risks faced by enterprises are closely related to the board of directors, management and other factors. According to the theory of risk factors, the risk caused by the external environment belongs to the system risk, which can not be eliminated by the individual enterprise. The other part of the risk belongs to the non system risk, which is the risk faced by the enterprise itself in the production and operation process. The non system risk is related to the management of the enterprise, and the operation or investment decision made by the management plays a decisive role in the operation risk, financial risk and control risk of an enterprise. Previous studies on the relationship between executive heterogeneity and corporate risk have mainly discussed managerial overconfidence [1]. Empirical tests using data from listed companies show that managerial overconfidence is significantly positively correlated with corporate risk-taking level, that is, more confident managers have more risk-taking ability, and that is to say, the more confident managers are, the stronger their risk-taking ability is. At the same time, when Ruijun Zhang et al. (2013) studied the relationship between executive compensation and enterprise risk, they found that the increase of executive compensation was significantly positively correlated with the level of enterprise risk-taking [2]. In addition, some scholars have also discussed the rights of CEO, executive gender, and executive experience in the military and other aspects related to the characteristics of managers [3-5].However, there are few literatures on the relationship between executive career expectation and enterprise risk. Based on this, this paper mainly studies the relationship between executive career expectation and enterprise risk, and verifies the mechanism between them.

\section{Theoretical Analysis and Research Hypothesis}

ISSN: 0010-8189 


\subsection{Executive career expectation and enterprise risk}

Executive career expectation refers to the expectation of executives on their own career, including the reputation, status, monetary compensation, tenure and so on. The higher career expectation of executives is a "double-edged sword" for the development of enterprises, which has both advantages and disadvantages, but it needs further empirical test whether the disadvantages outweigh the advantages or the advantages outweigh the disadvantages. This is mainly reflected in two aspects: on the one hand, executives with high career expectations will pay attention to more investment opportunities during their tenure, so as to obtain investment, improve business performance, and make the enterprise bigger and stronger. However, previous studies have shown that over investment of enterprises is easy to break the capital chain of enterprises and aggravate financial risks. At the same time, it will also make the allocation of resources invalid, thus increasing the risk of enterprises; on the other hand, executives who have high expectations of their career are more likely to establish a good market reputation in the industry and external manager market. The reputation of managers is the scarce resources accumulated by their long-term hard work and due diligence, which is hard to be reproduced and replaced in the capital market and securities market. In order to establish a good market reputation, managers will work harder and more seriously to improve corporate governance and improve corporate performance. According to the principal-agent theory, executives are entrusted by shareholders to manage the enterprise. Under the principal-agent relationship, agency conflicts will occur due to opportunism and self-interest behavior, which will lead to the risk degree faced by enterprises. However, in order to establish a good market reputation, executives with higher career expectations will pay more attention to the operation and management of enterprises, reduce the occurrence of agency conflicts, and then reduce the risks faced by enterprises.

Based on the above analysis, this paper believes that the relationship between career expectation and enterprise risk may be through two ways: One is the investment efficiency effect. Executives with high career expectations will make the enterprise face excessive investment, which will increase the risk of the enterprise; The other is based on reputation effect. Executives with higher career expectations will pay more attention to their reputation, thus reducing the agency conflicts caused by the principal-agent relationship and reducing the risks faced by enterprises. Therefore, hypothesis 1 is proposed:

Hypothesis 1A: the higher the career expectations of executives, the higher the risk faced by enterprises

Hypothesis $1 \mathrm{~b}$ : the higher the career expectations of executives, the lower the risk faced by enterprises

\subsection{Investment efficiency effect}

Based on the principal-agent theory proposed by Jensen (1976), the relationship between executives and shareholders belongs to the principal-agent relationship. In order to protect each other's rights and obligations, both shareholders and managers sign a principal-agent contract to ensure each other's interests [6]. At the same time, in order to effectively encourage executives to choose appropriate behaviors, shareholders will sign explicit incentive contracts to connect monetary compensation of executives with corporate performance [7].In order to obtain more monetary rewards, executives will choose a variety of ways to improve corporate performance, among which the most common way is to invest to maximize the use of the company's resources through capital investment decisions, thus promoting the improvement of enterprise performance. The existing research shows that executives will face two situations when they invest: one is under investment, and the other is over investment. For executives with high career expectations, in order to get more monetary compensation and improve enterprise performance faster, they will look for more investment opportunities and invest to improve the company's operating performance and enterprise value. However, some studies have shown that overinvestment can not only increase the value of enterprises, but also erode the value of enterprises, increase the risks faced by enterprises, reduce the utilization rate of assets and generate asset bubbles [8].Therefore, based on the analysis path of executive career expectation over 
investment and enterprise risk increase, this paper believes that the higher the career expectation of executives, the more likely they are to lead to excessive investment in the management of enterprises, thus increasing the risk of enterprises. Based on this, hypothesis 2 is proposed:

Hypothesis 2: under the same other conditions, the higher the career expectation, the more serious the over investment and the higher the enterprise risk.

\subsection{Reputation effect}

Based on the agent market reputation model proposed by Fama (1980), it is believed that the goal of executives employed by enterprises is not only to obtain more monetary compensation, but also to achieve self-worth and win good market reputation[9]. The personal reputation of executives is their intangible capital, which is a scarce resource, and the capital market and securities market are hard to be re engraved and replaced. Executives who have high expectation of their career will pay more attention to their personal reputation. In order to protect their personal reputation or enhance their personal reputation, they will take active management methods to strengthen the risk management of enterprises and reduce the risks faced by enterprises. Previous studies have shown that the managers who pay more attention to their own reputation pay more attention to the internal control operation of the enterprise. Major internal control defects exposed in the operation of the company will breed financial fraud, which will have a serious impact on the reputation of managers and career prospects [10].The research by Qingquan Xin et al. (2013) also shows that the company's management will be held accountable by the regulatory authorities due to the major defects in corporate governance, resulting in an increase in its reputation loss [11]. In other words, reputation has a spur effect on executives, which makes them pay more attention to corporate governance, improve the risk management of enterprises, improve the quality of internal control, and avoid the occurrence of "reputation risk". The research of Xie Zhihua (2007) shows that the stronger the internal control construction of an enterprise, the better its corporate governance mechanism is, the lower the risk faced by the enterprise, which is more conducive to the sustainable operation and development of the enterprise and enhance the enterprise value [12]. Based on the analysis path of reputation effect, the higher the expectation of executive career is, the more strict risk management is, the lower enterprise risk is. This paper holds that the higher the expectation of senior executive's career, they will pay more attention to the risk management of enterprises, improve the internal control of enterprises and reduce the risks faced by enterprises in order to maintain their personal reputation. Based on this, hypothesis 3 is proposed:

Hypothesis 3: under the same other conditions, the higher the career expectation is, the more strict the risk management is, the lower the risk faced by the enterprise.

To sum up, executive career expectations may have an impact on corporate risk through two opposite paths of investment efficiency effect and reputation effect. The comprehensive impact of executive career expectations on corporate risk, whether it is the effect of investment efficiency or reputation effect, needs to be further tested by empirical results.

\section{Design Research}

\subsection{Sample data and data sources}

This study selects A-share listed companies listed in Shanghai and Shenzhen Stock Exchange from 2008 to 2017 as the initial sample, and selects them according to the following criteria: (1) excluding financial and insurance enterprises, St enterprises (st, * st) and Pt enterprises; (2) eliminating the outliers of variables; (3) processing the continuous variables with $1 \%$ winsor2, and finally obtaining 6480 samples, using estata15 to process the data. All data were collected from CSMAR, RESSET and DIB databases. 


\subsection{Variable definition and selection}

\subsubsection{Explained variable}

The explanatory variable of this paper is enterprise risk. According to the research of Wengui Li et al. (2012) and Mingquan Sheng (2018), the volatility of enterprise profits (i.e. standard deviation) is used to measure enterprise risk $[13,14]$. In this paper, the standard deviation of earnings per share is used to measure the company's earnings volatility. In order to calculate the Earnings Fluctuation of listed companies more accurately and reasonably, this paper takes three years as the interval to calculate the standard deviation of earnings per share of the current year, one year behind and two years behind to measure the current risk. The calculation formula is as follows:

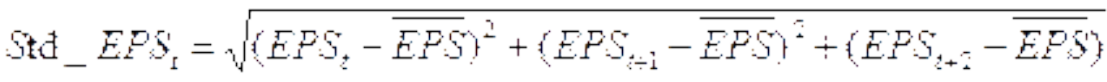

Among

$$
\overline{E P S}=\left(E P S_{-}+E P S_{-1}+E P S_{-2}\right) 3
$$

\subsubsection{Explanatory variables}

The explanatory variable of this paper is career expectation. The reason why the chairman is chosen as the research object is that the final decision-making power of Listed Companies in China is in the hands of the chairman, so the chairman is chosen as the research object. The index shows that the longer the chairman's tenure, the higher the career expectation.

\subsubsection{Intermediary variable}

Internal control quality (ICQ). The index is provided by DIB database. It is measured according to the internal control index disclosed by DIB database. In order to prevent large difference caused by too large value, the natural logarithm of the index is used for measurement. The higher the disclosure index is, the better the company's internal control is; conversely, the lower the index is, the worse the company's internal control is.

Investment efficiency (INV).Based on the investment efficiency model of Richardson (2006), this paper first calculates the expected normal investment level of the enterprise, and then uses the regression residual to measure the investment efficiency of the enterprise. The regression residuals of the model, ei,t, represent the inefficient investment expenditure of the company, where $\varepsilon \mathrm{i}, \mathrm{t}>0$ means that the company invests excessively, and $\varepsilon i, \mathrm{t}<0$ means underinvestment in the company. The calculation model is as follows:

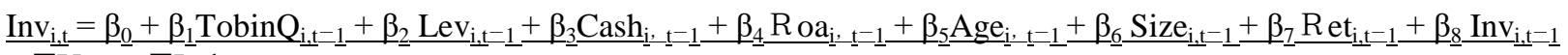
$+\sum$ Year $+\sum$ Industry $+\varepsilon_{i, t}$

3.2.4 control variable

In order to reduce the influence of other factors on the research results, the following variables are selected as control variables. The definition table of control variables is shown in Table 1.

\begin{tabular}{|c|c|c|}
\hline $\begin{array}{l}\text { Variable } \\
\text { symbol }\end{array}$ & Variable name & Definition and measurement \\
\hline Size & company size & $\begin{array}{l}\text { The natural logarithm of the company's total assets is used to measure the } \\
\text { size of the company }\end{array}$ \\
\hline Lev & financial leverage & $\begin{array}{l}\text { The asset liability ratio measures the company's financial leverage, which } \\
\text { is the ratio of the company's total liabilities to its total assets in the } \\
\text { current year }\end{array}$ \\
\hline Inde & Proportion of & Ratio of independent directors to total directors in the year \\
\hline
\end{tabular}

Table 1 Definition of control variables 


\begin{tabular}{|c|c|c|}
\hline & independent directors & \\
\hline Expense & agency cost & The higher the ratio, the higher the agency cost \\
\hline Boardsize & Number of directors & $\begin{array}{l}\text { This indicator is the total number of directors in the year disclosed by } \\
\text { CSMAR data }\end{array}$ \\
\hline Cash & $\begin{array}{l}\text { Proportion of monetary } \\
\text { capital }\end{array}$ & $\begin{array}{l}\text { The ratio of monetary funds disclosed for the annual financial statements } \\
\text { to the total assets of the company }\end{array}$ \\
\hline IPO_Age & Years of listing & The index is the year minus the IPO year of listed companies plus 1 \\
\hline Top10 & Equity concentration & $\begin{array}{l}\text { The sum of the shareholding ratio of the top ten shareholders of the } \\
\text { company }\end{array}$ \\
\hline Grow & Company growth & $\begin{array}{l}\text { The ratio of the difference between the operating revenue minus the } \\
\text { operating income of the previous period and the operating income of the } \\
\text { previous period }\end{array}$ \\
\hline Dual & $\begin{array}{l}\text { Two posts at the same } \\
\text { time }\end{array}$ & $\begin{array}{l}\text { When the general manager and the chairman are the same person, the } \\
\text { value is } 1 \text {; if not, the value is } 0\end{array}$ \\
\hline SR_weight & $\begin{array}{l}\text { Separation rate of two } \\
\text { rights }\end{array}$ & Ownership ratio / control ratio of actual controller \\
\hline
\end{tabular}

\subsection{Model setting}

In order to test hypothesis 1 , we construct model 1 to test the comprehensive influence of executive career expectation and enterprise risk

Risk $=\alpha 0+\alpha 1$ Career_exp $+\alpha 2$ Size $+\alpha 3$ Lev $+\alpha 4$ Inde $+\alpha 5$ Expense $+\alpha 6$ Boardsize $+\alpha 7$ Cash $+\alpha 8$ IPO_age $+\alpha 9$ Top $10+\alpha 10 \mathrm{Gr}$ ow $+\alpha 11$ Dual $+\alpha 12$ SR_weight $+\alpha 13 \sum$ Year $+\alpha 14 \sum$ Ind $+\varepsilon t$

3.3.1 Investment efficiency effect

In order to test hypothesis 2 , whether the impact of executive career expectation on enterprise risk is affected by investment effect, an investment effect intermediary model is established to test.

Risk $=\alpha 0+\alpha 1$ Career_exp $+\alpha 2$ Size $+\alpha 3$ Lev $+\alpha 4$ Inde $+\alpha 5$ Expense $+\alpha 6$ Boardsize $+\alpha 7$ Cash $+\alpha 8$ IPO_age $+\alpha 9$ Top $10+\alpha 10 \mathrm{Gr}$ ow $+\alpha 11$ Dual $+\alpha 12$ SR_weight $+\alpha 13 \sum$ Year $+\alpha 14 \sum$ Ind $+\varepsilon t$

Inv $=\beta 0+\beta 1$ Career_exp $+\beta 2$ Size $+\beta 3 \mathrm{Lev}+\beta 4$ Inde $+\beta 5$ Expense $+\beta 6$ Boardsize $+\beta 7$ Cash $+\beta 8$ IPO_age $+\beta 9$ Top $10+\beta 10$ Gro $w+\beta 11$ Dual $+\beta 12$ SR_weight $+\beta 13 \sum$ Year $+\beta 14 \sum$ Ind $+\varepsilon t$

Risk $=\gamma 0+\gamma 1$ Career_exp $+\gamma 2$ Inv $+\gamma 3$ Size $+\gamma 4$ Lev $+\gamma 5$ Inde $+\gamma 6$ Expense $+\gamma 7$ Boardsize $+\gamma 8$ Cash $+\gamma 9$ IPO_age $+\gamma 10$ Top $10+$ $\gamma 11$ Grow $+\gamma 12$ Dual $+\gamma 13$ SR_weight $+\gamma 14 \sum$ Year $+\gamma 15 \sum$ Ind $+\varepsilon t$

In the above three models, if $\alpha$ is significant in model (2), it indicates that executive career expectation has an impact on enterprise risk; in model (3), $\beta 1$ is significant, which indicates that executive career expectation has an impact on investment efficiency; if $\gamma 1$ is not significant and $\gamma 2$ is significant in model (4), there is a complete mediating effect. If $\gamma 1$ is significant and $\beta 1, \gamma 2$ and $\gamma 1$ in model (3) and model (4) are the same, there is a partial mediating effect.

\subsubsection{Reputation effect}

In order to test hypothesis 3 , whether the impact of executive career expectation on corporate risk is affected by reputation effect, a reputation effect intermediary model is established to test.

Risk $=\alpha 0+\alpha 1$ Career_exp $+\alpha 2$ Size $+\alpha 3$ Lev $+\alpha 4$ Inde $+\alpha 5$ Expense $+\alpha 6$ Boardsize $+\alpha 7$ Cash $+\alpha 8$ IPO_age $+\alpha 9$ Top $10+\alpha 10$ Gr ow $+\alpha 11$ Dual $+\alpha 12$ SR_weight $+\alpha 13 \sum$ Year $+\alpha 14 \sum$ Ind $+\varepsilon t$

ICD $=\beta 0+\beta 1$ Career_exp $+\beta 2$ Size $+\beta 3$ Lev $+\beta 4$ Inde $+\beta 5$ Expense $+\beta 6$ Boardsize $+\beta 7$ Cash $+\beta 8$ IPO_age $+\beta 9$ Top $10+\beta 10 \mathrm{Gr}$ 
Risk $=\gamma 0+\gamma 1$ Career_exp $+\gamma 2$ ICD $+\gamma 3$ Size $+\gamma 4 \mathrm{Lev}+\gamma 5$ Inde $+\gamma 6$ Expense $+\gamma 7$ Boardsize $+\gamma 8$ Cash $+\gamma 9$ IPO_age $+\gamma 10$ Top 10 $+\gamma 11$ Grow $+\gamma 12$ Dual $+\gamma 13$ SR_weight $+\gamma 14 \sum$ Year $+\gamma 15 \sum$ Ind $+\varepsilon t$

The test method to judge whether there is intermediary effect of reputation effect is described in the test of investment effect.

\section{Empirical Analysis}

\subsection{Descriptive statistics}

Table 2 shows the descriptive statistical results of the main variables. The maximum value of enterprise risk is 1.482 , and the minimum value is 0.008 , which indicates that the enterprise risk faced by sample companies varies greatly between different industries and enterprises. The minimum value of age is 0.152 , and the maximum value is 2.639 , which indicates that there is a big difference in the length of senior executive's; tenure, and there is also a big difference in the career expectations of executives; the maximum value of investment efficiency (INV) is 0.3 , the minimum value is 0.001 ; the minimum value of internal control quality (ICD) is 5.923 , the maximum value is 6.772 , which indicates that the internal control of sample enterprises is relatively good, and the difference is small. The descriptive statistics of other control variables are in normal level, but some indicators also show that there are some differences between different industries and different enterprises.

Table 2 Descriptive Statistics

\begin{tabular}{lcccccc}
\hline variable & $\mathrm{N}$ & mean & $\mathrm{SD}$ & Min & P50 & Max \\
\hline Risk & 6201 & 0.259 & 0.276 & 0.008 & 0.169 & 1.482 \\
Career_Exp & 6201 & 1.463 & 0.745 & 0.152 & 1.609 & 2.639 \\
Inv & 6201 & 0.045 & 0.051 & 0.001 & 0.030 & 0.300 \\
ICD & 6201 & 6.496 & 0.118 & 5.923 & 6.517 & 6.772 \\
Size & 6201 & 22.06 & 1.151 & 19.74 & 21.93 & 25.39 \\
Lev & 6201 & 0.450 & 0.201 & 0.060 & 0.447 & 0.875 \\
Inde & 6201 & 0.371 & 0.053 & 0.308 & 0.333 & 0.571 \\
Expense & 6201 & 0.095 & 0.073 & 0.009 & 0.080 & 0.435 \\
Boardsize & 6201 & 8.780 & 1.682 & 5 & 9 & 15 \\
Cash & 6201 & 0.174 & 0.119 & 0.016 & 0.142 & 0.585 \\
IPO age & 6201 & 2.317 & 0.598 & 1.099 & 2.398 & 3.219 \\
Top10 & 6201 & 0.552 & 0.152 & 0.220 & 0.557 & 0.867 \\
Grow & 6201 & 0.150 & 0.298 & 0.130 & 0.110 & 1.316 \\
Dual & 6201 & 0.249 & 0.432 & 0 & 0 & 1 \\
SR weight & 6201 & 5.839 & 7.995 & 0 & 0.065 & 28.80 \\
\hline & & & & & &
\end{tabular}

4.2 Correlation analysis

Table 3 is the correlation analysis table of variables. From the correlation coefficient of each variable, there is no serious multicollinearity among the explained variable, the explained variable and the control variable. From the correlation and sign of each variable, there is a significant negative correlation between executive career expectation and enterprise risk, that is, the higher the executive career expectation, the lower the risk faced by the enterprise; there is a significant positive correlation between investment efficiency and enterprise risk, that is, excessive investment may lead to the increase of enterprise risk; there is a negative correlation between internal control and enterprise risk at a significant level of $10 \%$. That is, the better the internal control is, the lower the enterprise risk is. From the results of correlation analysis, the correlation between variables and symbols are consistent with expectations. 
Table 3 Correlation Analysis

\begin{tabular}{|c|c|c|c|c|c|c|c|c|c|c|c|c|c|c|c|}
\hline & Risk & $\begin{array}{c}\text { Career } \\
\text { Exp }\end{array}$ & Inv & ICD & Size & Lev & Inde & $\begin{array}{c}\text { Expe } \\
\text { nse }\end{array}$ & $\begin{array}{l}\text { Boar } \\
\text { dsize }\end{array}$ & Cash & $\begin{array}{c}\mathrm{IPO}_{-} \\
\text {Age }\end{array}$ & $\begin{array}{c}\text { Top1 } \\
0\end{array}$ & $\begin{array}{c}\text { Gro } \\
\text { w }\end{array}$ & Dual & $\begin{array}{l}\text { SR_w } \\
\text { eight }\end{array}$ \\
\hline Risk & 1.000 & & & & & & & & & & & & & & \\
\hline Career & -0.06 & 1.000 & & & & & & & & & & & & & \\
\hline \multirow[t]{3}{*}{ _Exp } & $4 * * *$ & & & & & & & & & & & & & & \\
\hline & $(0.00$ & & & & & & & & & & & & & & \\
\hline & 0) & & & & & & & & & & & & & & \\
\hline \multirow[t]{3}{*}{ Inv } & $\begin{array}{c}0.029 \\
* *\end{array}$ & $\begin{array}{c}-0.054 \\
* * *\end{array}$ & 1.000 & & & & & & & & & & & & \\
\hline & $(0.02$ & $(0.000$ & & & & & & & & & & & & & \\
\hline & 3) & ) & & & & & & & & & & & & & \\
\hline \multirow[t]{4}{*}{ ICD } & -0.02 & 0.070 & -0.01 & 1.000 & & & & & & & & & & & \\
\hline & $1 *$ & $* * *$ & 7 & & & & & & & & & & & & \\
\hline & $(0.09$ & $(0.000$ & (0.19 & & & & & & & & & & & & \\
\hline & 8) & ) & 2) & & & & & & & & & & & & \\
\hline \multirow[t]{4}{*}{ Size } & 0.233 & 0.029 & -0.05 & 0.194 & 1.000 & & & & & & & & & & \\
\hline & $* * *$ & $* *$ & $1 * * *$ & $* * *$ & & & & & & & & & & & \\
\hline & $(0.00$ & $(0.025$ & $(0.00$ & $(0.00$ & & & & & & & & & & & \\
\hline & $0)$ & ) & 0) & 0) & & & & & & & & & & & \\
\hline \multirow[t]{4}{*}{ Lev } & 0.133 & -0.048 & -0.06 & -0.03 & 0.457 & 1.000 & & & & & & & & & \\
\hline & $* * *$ & *** & $8 * * *$ & $1 * *$ & $* * *$ & & & & & & & & & & \\
\hline & $(0.00$ & $(0.000$ & $(0.00$ & $(0.01$ & $(0.00$ & & & & & & & & & & \\
\hline & 0) & ) & 0) & 6) & 0) & & & & & & & & & & \\
\hline \multirow[t]{4}{*}{ Inde } & 0.004 & 0.046 & 0.027 & 0.014 & 0.041 & -0.00 & 1.000 & & & & & & & & \\
\hline & & $* * *$ & ** & & $* * *$ & 8 & & & & & & & & & \\
\hline & $(0.77$ & $(0.000$ & $(0.03$ & $(0.25$ & $(0.00$ & $(0.52$ & & & & & & & & & \\
\hline & 3) & ) & 5) & 8) & 1) & 8) & & & & & & & & & \\
\hline \multirow{4}{*}{$\begin{array}{l}\text { Expen } \\
\text { se }\end{array}$} & 0.033 & 0.007 & 0.096 & -0.18 & -0.30 & -0.32 & 0.039 & 1.000 & & & & & & & \\
\hline & $* * *$ & & $* * *$ & $6^{* * * *}$ & $7 * * *$ & $7 * * *$ & $* * *$ & & & & & & & & \\
\hline & $(0.00$ & $(0.577$ & $(0.00$ & $(0.00$ & $(0.00$ & $(0.00$ & $(0.00$ & & & & & & & & \\
\hline & 9) & ) & 0) & 0) & 0) & 0) & 2) & & & & & & & & \\
\hline \multirow{4}{*}{$\begin{array}{l}\text { Board } \\
\text { size }\end{array}$} & 0.057 & -0.035 & -0.03 & 0.094 & 0.230 & 0.138 & -0.43 & -0.07 & 1.000 & & & & & & \\
\hline & *** & $* * *$ & $8 * * *$ & $* * *$ & $* * *$ & *** & $6 * * *$ & $1 * * *$ & & & & & & & \\
\hline & $(0.00$ & $(0.006$ & $(0.00$ & $(0.00$ & $(0.00$ & $(0.00$ & $(0.00$ & $(0.00$ & & & & & & & \\
\hline & 0) & ) & 3) & 0) & 0) & 0) & 0) & 0) & & & & & & & \\
\hline \multirow[t]{4}{*}{ Cash } & -0.01 & 0.007 & 0.008 & 0.103 & -0.15 & -0.29 & 0.002 & 0.119 & -0.01 & 1.000 & & & & & \\
\hline & 1 & & & $* * *$ & $6 * * *$ & $9 * * *$ & & $* * *$ & 4 & & & & & & \\
\hline & $(0.36$ & $(0.580$ & $(0.52$ & $(0.00$ & $(0.00$ & $(0.00$ & $(0.89$ & $(0.00$ & $(0.26$ & & & & & & \\
\hline & 8) & ) & 2) & 0) & 0) & 0) & 7) & 0) & 2) & & & & & & \\
\hline \multirow{4}{*}{$\begin{array}{l}\text { IPO_- } \\
\text { Age }\end{array}$} & 0.007 & -0.026 & -0.10 & -0.09 & 0.347 & 0.268 & 0.010 & -0.02 & 0.081 & -0.15 & 1.000 & & & & \\
\hline & & $* *$ & $3 * * *$ & $8 * * *$ & $* * *$ & *** & & 1 & *** & $3 * * *$ & & & & & \\
\hline & $(0.57$ & $(0.039$ & $(0.00$ & $(0.00$ & $(0.00$ & $(0.00$ & $(0.41$ & $(0.10$ & $(0.00$ & $(0.00$ & & & & & \\
\hline & 6) & ) & 0) & 0) & 0) & 0) & 4) & 4) & 0) & 0) & & & & & \\
\hline \multirow[t]{4}{*}{ Top10 } & 0.076 & -0.086 & 0.085 & 0.147 & 0.158 & -0.04 & -0.00 & -0.14 & 0.025 & 0.085 & -0.29 & 1.00 & & & \\
\hline & $* * *$ & $* * *$ & *** & $* * *$ & $* * *$ & $9 * * *$ & 6 & $1 * * *$ & ** & $* * *$ & $3 * * *$ & 0 & & & \\
\hline & $(0.00$ & $(0.000$ & $(0.00$ & $(0.00$ & $(0.00$ & $(0.00$ & $(0.61$ & $(0.00$ & $(0.04$ & $(0.00$ & $(0.00$ & & & & \\
\hline & 0) & ) & 0) & 0) & 0) & 0) & 8) & 0) & 5) & 0) & 0) & & & & \\
\hline \multirow[t]{4}{*}{ Grow } & -0.01 & 0.025 & 0.135 & 0.216 & 0.115 & 0.058 & 0.005 & -0.16 & -0.00 & 0.051 & -0.08 & 0.12 & 1.00 & & \\
\hline & 6 & $*$ & $* * *$ & *** & *** & $* * *$ & & $4 * * *$ & 4 & $* * *$ & $5 * * *$ & $2 * * *$ & 0 & & \\
\hline & $(0.22$ & $(0.054$ & $(0.00$ & $(0.00$ & $(0.00$ & $(0.00$ & $(0.72$ & $(0.00$ & $(0.75$ & $(0.00$ & $(0.00$ & $(0.00$ & & & \\
\hline & 0) & ) & 0) & 0) & 0) & 0) & 3) & 0) & 3) & 0) & 0) & 0) & & & \\
\hline \multirow[t]{4}{*}{ Dual } & -0.01 & 0.063 & 0.023 & 0.005 & -0.08 & -0.09 & 0.128 & 0.034 & -0.17 & 0.049 & -0.18 & 0.00 & 0.04 & 1.000 & \\
\hline & 2 & $* * *$ & $*$ & & $9 * * *$ & $1 * * *$ & $* * *$ & $* * *$ & $3 * * *$ & $* * *$ & $4 * * *$ & 7 & $0 * * *$ & & \\
\hline & $(0.34$ & $(0.000$ & (0.07 & $(0.66$ & $(0.00$ & $(0.00$ & $(0.00$ & $(0.00$ & $(0.00$ & $(0.00$ & $(0.00$ & $(0.60$ & $(0.00$ & & \\
\hline & 0) & ) & 2) & 8) & 0) & 0) & 0) & 8) & 0) & 0) & 0) & 4) & 1) & & \\
\hline SR_w & 0.027 & -0.005 & -0.01 & 0.071 & 0.066 & 0.073 & -0.08 & -0.08 & 0.066 & 0.001 & 0.085 & 0.13 & 0.01 & -0.09 & 1.000 \\
\hline eight & ** & & 0 & $* * *$ & $* * *$ & $* * *$ & $8 * * *$ & $0 * * *$ & $* * *$ & & $* * *$ & $3 * * *$ & 4 & $0 * * *$ & \\
\hline & $(0.03$ & $(0.679$ & $(0.42$ & $(0.00$ & $(0.00$ & $(0.00$ & $(0.00$ & $(0.00$ & $(0.00$ & $(0.94$ & $(0.00$ & $(0.00$ & $(0.27$ & $(0.00$ & \\
\hline & 7) & ) & 3) & 0) & 0) & 0) & 0) & 0) & 0) & 4) & 0) & 0) & 5) & $0)$ & \\
\hline
\end{tabular}

Standard errors in parentheses $* \mathrm{p}<0.10, * * \mathrm{p}<0.05, * * * \mathrm{p}<0.01$

\subsection{Regression analysis}

4.3.1 Executive career expectation and enterprise risk

Table 4 shows the test results of the total effect of executive career expectation and enterprise risk. In Table 4 , 
column (1) of Table 4 shows the regression results of uncontrolled industries, years and other control variables. The results show that executive career expectation has a negative correlation with enterprise risk at the significance level of $1 \%$, that is, the higher the executive career expectation, the lower the risk faced by the enterprise; column (2) is the regression result without other control variables, but it controls the regression results of industry and after the year. The results show that there is a significant negative correlation between executive career expectation and enterprise risk at the level of $1 \%$; column (3) is the regression result of adding other control variables and controlling industry and year, and the results show that it is still negatively correlated at the significance level of $1 \%$. After adding other control variables, enterprise size, financial leverage and agency cost are negatively correlated with enterprise risk at the significance level of $1 \%$, which is consistent with the results of previous studies. The regression results of the total effect show that hypothesis $1 \mathrm{~b}$ is verified, that is, the higher the expectation of executives on their career, the lower the risk faced by enterprises.

Table 4 Expectation and career risk of executives

\begin{tabular}{|c|c|c|c|}
\hline \multicolumn{4}{|c|}{ Table 4 Expectation and career risk of executives } \\
\hline & $(1)$ & $(2)$ & (3) \\
\hline A kind ofcons & $\begin{array}{c}0.293 * * * \\
(0.01)\end{array}$ & $\begin{array}{c}0.637 * * * \\
(0.05)\end{array}$ & $\begin{array}{c}-0.840 * * * \\
(0.11)\end{array}$ \\
\hline Career_Exp & $\begin{array}{c}-0.024 * * * \\
(0.00)\end{array}$ & $\begin{array}{c}-0.024 * * * \\
(0.00)\end{array}$ & $\begin{array}{c}-0.025 * * * \\
(0.00)\end{array}$ \\
\hline Size & & & $\begin{array}{c}0.070 * * * \\
(0.00)\end{array}$ \\
\hline Lev & & & $\begin{array}{c}0.117 * * * \\
(0.03)\end{array}$ \\
\hline Inde & & & $\begin{array}{r}-0.075 \\
(0.08)\end{array}$ \\
\hline Expense & & & $\begin{array}{c}0.286^{* * * *} \\
(0.06)\end{array}$ \\
\hline Boardsize & & & $\begin{array}{l}-0.004 \\
(0.00)\end{array}$ \\
\hline Cash & & & $\begin{array}{c}0.082 * * \\
(0.03)\end{array}$ \\
\hline IPO_Age & & & $\begin{array}{c}-0.024 * * * \\
(0.01)\end{array}$ \\
\hline Top10 & & & $\begin{array}{c}0.053 * * \\
(0.03)\end{array}$ \\
\hline Grow & & & $\begin{array}{c}-0.041 * * * \\
(0.01)\end{array}$ \\
\hline Dual & & & $\begin{array}{l}0.006 \\
(0.01)\end{array}$ \\
\hline SR_weight & & & $\begin{array}{l}0.000 \\
(0.00)\end{array}$ \\
\hline $\begin{array}{l}\text { industry } \\
\text { year }\end{array}$ & $\begin{array}{l}\text { Uncontrolled } \\
\text { Uncontrolled }\end{array}$ & $\begin{array}{l}\text { control } \\
\text { control }\end{array}$ & $\begin{array}{l}\text { control } \\
\text { control }\end{array}$ \\
\hline$R^{2}$ & 0.004 & 0.023 & 0.100 \\
\hline adj. R2 & 0.004 & 0.019 & 0.095 \\
\hline$N$ & 6201 & 6201 & 6201 \\
\hline
\end{tabular}

Standard errors in parentheses $* \mathrm{p}<0.10, * * \mathrm{p}<0.05, * * * \mathrm{p}<0.01$

4.3.2 Test and analysis of two effects

Columns (1) - (3) in Table 5 are the regression results of investment effect, and columns (4) - (6) are regression results of reputation effect. The first column is the regression result of executive career and enterprise risk, and the result is negatively correlated with the significance level of $1 \%$; the second column is the regression result of executive career expectation and investment efficiency, which shows that the higher the expectation of their career is, the more likely they are to increase investment. Column (3) is the result of adding the intermediary variable 
investment efficiency. The results show that after adding the intermediary variable, the career expectation of executives is positively correlated with the enterprise risk at the significance level of 5\%, and the investment efficiency is positively correlated with the enterprise risk at the level of 5\%, which indicates that the higher the expectation of the senior executives on their career, the more likely they are to increase investment, which will lead to the increase of risks faced by enterprises, i.e. hypothesis 2 is verified. Column (4) is the result of executive career expectation and enterprise risk, which will not be repeated here; column (5) is the regression result of executive career expectation and internal control, and the result shows that at the level of $1 \%$, the two show a significant positive correlation, indicating that the higher the expectation of their own career, the more attention they attach to internal control in order to maintain their good reputation; Column (6) is the regression results after adding internal control variables. The results show that after adding internal control variables, executive career expectation and enterprise risk are significantly negatively correlated with enterprise risk at the level of $1 \%$. Internal control and enterprise risk also show a significant negative correlation at the level of $1 \%$, indicating that the higher the expectation of their own career, the more attention they pay to their own reputation, which will also improve the internal control construction of enterprises, and then reduce the risks faced by enterprises. Hypothesis 3 is verified.

In the total effect test of executive professional reputation expectation and enterprise risk, there is a significant negative correlation between them. Table 5 tests the two effects. The results show that the investment efficiency effect increases the risk faced by the enterprise, and the reputation effect reduces the risk faced by the enterprise. Therefore, under the effect of the two effects, the role between the career expectation of senior executives and the enterprise risk is mainly dominated by the reputation effect, that is, the higher the expectation of their career, the more attention they pay to their own reputation. In order to maintain the reputation, they will pay attention to the internal control and risk management of the enterprise, so as to reduce the risk faced by the enterprise.

Table 5 Regression results of two effects

\begin{tabular}{|c|c|c|c|c|c|c|}
\hline & $(1)$ & $(2)$ & (3) & $(4)$ & $(5)$ & $(6)$ \\
\hline & \multicolumn{3}{|c|}{ Investment efficiency effect } & \multicolumn{3}{|c|}{ Reputation effect } \\
\hline & Risk & Inv & Risk & Risk & ICD & Risk \\
\hline Career_Exp & $\begin{array}{c}-0.025 * * * \\
(0.00)\end{array}$ & $\begin{array}{c}0.004 * * * \\
(0.00)\end{array}$ & $\begin{array}{c}0.021 * * \\
(0.00)\end{array}$ & $\begin{array}{c}-0.025 * * * \\
(0.00)\end{array}$ & $\begin{array}{c}0.010 * * * \\
(0.00)\end{array}$ & $\begin{array}{c}-0.023 * * * \\
(0.00)\end{array}$ \\
\hline Inv & & & $\begin{array}{c}0.169 * * \\
(0.08)\end{array}$ & & & \\
\hline ICD & & & & & & $\begin{array}{c}-0.230 * * * \\
(0.04)\end{array}$ \\
\hline Size & $\begin{array}{c}0.070 * * * \\
(0.00)\end{array}$ & $\begin{array}{l}0.000 \\
(0.00)\end{array}$ & $\begin{array}{c}0.070 * * * \\
(0.00)\end{array}$ & $\begin{array}{c}0.070 * * * \\
(0.00)\end{array}$ & $\begin{array}{c}0.036 * * * \\
(0.00)\end{array}$ & $\begin{array}{c}0.079 * * * \\
(0.00)\end{array}$ \\
\hline Lev & $\begin{array}{c}0.117 * * * \\
(0.03)\end{array}$ & $\begin{array}{l}-0.002 \\
(0.00)\end{array}$ & $\begin{array}{c}0.117 * * * \\
(0.03)\end{array}$ & $\begin{array}{c}0.117 * * * \\
(0.03)\end{array}$ & $\begin{array}{c}-0.126 * * * \\
(0.01)\end{array}$ & $\begin{array}{c}0.088 * * * \\
(0.03)\end{array}$ \\
\hline Inde & $\begin{array}{l}-0.075 \\
(0.08)\end{array}$ & $\begin{array}{l}0.016 \\
(0.01)\end{array}$ & $\begin{array}{l}-0.078 \\
(0.08)\end{array}$ & $\begin{array}{l}-0.075 \\
(0.08)\end{array}$ & $\begin{array}{c}0.056^{*} \\
(0.03)\end{array}$ & $\begin{array}{l}-0.062 \\
(0.08)\end{array}$ \\
\hline Expense & $\begin{array}{c}0.286 * * * \\
(0.06)\end{array}$ & $\begin{array}{c}0.078 * * * \\
(0.01)\end{array}$ & $\begin{array}{c}0.273 * * * \\
(0.06)\end{array}$ & $\begin{array}{c}0.286^{* * *} \\
(0.06)\end{array}$ & $\begin{array}{c}-0.179 * * * \\
(0.02)\end{array}$ & $\begin{array}{c}0.245 * * * \\
(0.06)\end{array}$ \\
\hline Boardsize & $\begin{array}{l}-0.004 \\
(0.00)\end{array}$ & $\begin{array}{c}-0.001 * \\
(0.00)\end{array}$ & $\begin{array}{l}-0.004 \\
(0.00)\end{array}$ & $\begin{array}{l}-0.004 \\
(0.00)\end{array}$ & $\begin{array}{c}0.002 * * \\
(0.00)\end{array}$ & $\begin{array}{l}-0.003 \\
(0.00)\end{array}$ \\
\hline Cash & $\begin{array}{c}0.082 * * \\
(0.03)\end{array}$ & $\begin{array}{c}-0.016 \text { *** } \\
(0.01)\end{array}$ & $\begin{array}{c}0.085^{* *} * \\
(0.03)\end{array}$ & $\begin{array}{c}0.082 * * \\
(0.03)\end{array}$ & $\begin{array}{c}0.050 * * * \\
(0.01)\end{array}$ & $\begin{array}{c}0.093 * * * \\
(0.03)\end{array}$ \\
\hline IPO_Age & $\begin{array}{c}-0.024 * * * \\
(0.01)\end{array}$ & $\begin{array}{c}-0.006 * * * \\
(0.00)\end{array}$ & $\begin{array}{c}-0.023 * * * \\
(0.01)\end{array}$ & $\begin{array}{c}-0.024 * * * \\
(0.01)\end{array}$ & $\begin{array}{c}-0.004 \\
(0.00)\end{array}$ & $\begin{array}{c}-0.025 * * * \\
(0.01)\end{array}$ \\
\hline Top10 & $\begin{array}{c}0.053 * * \\
(0.03)\end{array}$ & $\begin{array}{c}0.021 * * * \\
(0.00)\end{array}$ & $\begin{array}{c}0.049 * \\
(0.03)\end{array}$ & $\begin{array}{c}0.053 * * \\
(0.03)\end{array}$ & $\begin{array}{c}0.025 * * \\
(0.01)\end{array}$ & $\begin{array}{c}0.058 * * \\
(0.03)\end{array}$ \\
\hline Grow & $\begin{array}{c}-0.041 * * * \\
(0.01)\end{array}$ & $\begin{array}{c}0.025 * * * \\
(0.00)\end{array}$ & $\begin{array}{c}-0.045 * * * \\
(0.01)\end{array}$ & $\begin{array}{c}-0.041 * * * \\
(0.01)\end{array}$ & $\begin{array}{c}0.063 * * * \\
(0.01)\end{array}$ & $\begin{array}{c}-0.027 * \\
(0.01)\end{array}$ \\
\hline Dual & 0.006 & -0.000 & 0.006 & 0.006 & 0.003 & 0.007 \\
\hline
\end{tabular}




\begin{tabular}{cccc|ccc} 
& $(0.01)$ & $(0.00)$ & $(0.01)$ & $(0.01)$ & $(0.00)$ & $(0.01)$ \\
SR_weight & 0.000 & -0.000 & 0.000 & 0.000 & $0.001 * * *$ & 0.000 \\
& $(0.00)$ & $(0.00)$ & $(0.00)$ & $(0.00)$ & $(0.00)$ & $(0.00)$ \\
industry & control & control & control & control & control & control \\
year & control & control & control & control & control & control \\
\hline$R^{2}$ & 0.100 & 0.077 & 0.101 & 0.100 & 0.236 & 0.108 \\
adj. R2 & 0.095 & 0.072 & 0.096 & 0.095 & 0.232 & 0.102 \\
$N$ & 6201 & 6201 & 6201 & 6201 & 6201 & 6201 \\
\hline
\end{tabular}

Standard errors in parentheses $* \mathrm{p}<0.10, * * \mathrm{p}<0.05, * * * \mathrm{p}<0.01$

\subsubsection{Further analysis: grouping test}

Through the test of the above two effects, we can know that the relationship between the career expectation of executives and enterprise risk is mainly due to the dominant role of reputation effect, that is, the higher the career expectations of executives, the more attention they pay to their own reputation, in order not to fall into the crisis of "reputation risk", the more attention they pay to the internal control of enterprises and reduce the risks faced by enterprises. On this basis, according to the nature of enterprises, the research group conducted a group test on reputation effect. In China, the nature of enterprises can be divided into two categories: one is state-owned holding, that is, state-owned enterprises; the other is private holding, that is, private enterprises. Considering that the chairman of the board of directors of state-owned enterprises is mainly appointed by the central government or government departments, while the chairman of private enterprises is mainly the founder or external manager of the enterprise, whether the different appointment methods of the chairman affect the career expectation of senior executives, whether there are differences in the maintenance of personal reputation, and then affect the enterprise risk? For this question, a further group test is conducted to test whether the reputation effect still exists.

Table 6 shows the results of group test. The results show that: in the sample group of state-owned enterprises and private enterprises, the relationship between career expectation and enterprise risk is significant, which is basically consistent with the previous test results. However, the regression coefficient of the sample group of state-owned enterprises is lower than that of the sample group of private enterprises. The results show that in the sample group of private enterprises, the correlation between the career expectation of executives and enterprise risk is higher, that is, the chairman of private enterprises pays more attention to their own professional reputation and internal control construction. This may be due to the fact that the reputation of the chairman of a private enterprise is mainly established and maintained by his own hard work, while the chairman of a state-owned enterprise is appointed by the government. Regardless of the risk faced by the enterprise or supported by the state or the government, the expectation of state-owned enterprise executives on their career is low.

Table 6 grouping test results

\begin{tabular}{cccc|ccc}
\hline & \multicolumn{3}{c|}{ state-owned enterprise } & \multicolumn{3}{c}{ privately operated } \\
& Risk & ICD & Risk & Risk & ICD & Risk \\
\hline Career_Exp & $-0.023^{* * *}$ & $0.009^{* * *}$ & $-0.021^{* * *}$ & $-0.035^{* * *}$ & $0.013^{* * *}$ & $-0.033^{* * *}$ \\
& $(0.01)$ & $(0.00)$ & $(0.01)$ & $(0.01)$ & $(0.00)$ & $(0.01)$ \\
ICD & & & $-0.201^{* * *}$ & & & $-0.267 * * *$ \\
& & & $(0.06)$ & & & $(0.06)$ \\
Size & $0.072^{* * *}$ & $0.041^{* * *}$ & $0.083^{* * *}$ & $0.061^{* * *}$ & $0.032^{* * *}$ & $0.068^{* * *}$ \\
& $(0.01)$ & $(0.00)$ & $(0.01)$ & $(0.01)$ & $(0.00)$ & $(0.01)$ \\
Lev & $0.206^{* * *}$ & $-0.137 * * *$ & $0.170^{* * *}$ & 0.042 & $-0.122^{* * *}$ & 0.017 \\
& $(0.04)$ & $(0.02)$ & $(0.04)$ & $(0.04)$ & $(0.01)$ & $(0.04)$ \\
Inde & -0.086 & -0.007 & -0.088 & -0.028 & $0.097^{* *}$ & -0.008 \\
& $(0.11)$ & $(0.05)$ & $(0.11)$ & $(0.10)$ & $(0.04)$ & $(0.10)$ \\
Expense & 0.127 & $-0.170^{* * *}$ & 0.083 & $0.318^{* * *}$ & $-0.173^{* * *}$ & $0.282^{* * *}$ \\
& $(0.10)$ & $(0.04)$ & $(0.10)$ & $(0.07)$ & $(0.03)$ & $(0.07)$ \\
Boardsize & $-0.007 * *$ & 0.002 & $-0.007 * *$ & 0.003 & 0.002 & 0.003 \\
& $(0.00)$ & $(0.00)$ & $(0.00)$ & $(0.00)$ & $(0.00)$ & $(0.00)$
\end{tabular}

ISSN: 0010-8189 


\begin{tabular}{cccc|ccc} 
Cash & $0.137 * * *$ & $0.067 * * *$ & $0.154 * * *$ & 0.055 & $0.032 *$ & 0.062 \\
& $(0.05)$ & $(0.02)$ & $(0.05)$ & $(0.05)$ & $(0.02)$ & $(0.05)$ \\
IPO_Age & -0.011 & $-0.011 * *$ & -0.014 & -0.018 & -0.002 & -0.018 \\
& $(0.01)$ & $(0.00)$ & $(0.01)$ & $(0.01)$ & $(0.00)$ & $(0.01)$ \\
Top10 & 0.006 & -0.010 & 0.003 & $0.127 * * *$ & $0.043 * * *$ & $0.136 * * *$ \\
& $(0.04)$ & $(0.02)$ & $(0.04)$ & $(0.04)$ & $(0.01)$ & $(0.04)$ \\
Grow & -0.029 & $0.073 * * *$ & -0.010 & $-0.043 * *$ & $0.059 * * *$ & -0.030 \\
& $(0.02)$ & $(0.01)$ & $(0.02)$ & $(0.02)$ & $(0.01)$ & $(0.02)$ \\
Dual & $0.062 * * *$ & -0.006 & $0.060 * * *$ & $-0.021 * *$ & $0.008 * *$ & $-0.019 * *$ \\
& $(0.02)$ & $(0.01)$ & $(0.02)$ & $(0.01)$ & $(0.00)$ & $(0.01)$ \\
SR_weight & 0.001 & $0.001 * * *$ & 0.001 & -0.001 & $0.001 * * *$ & -0.001 \\
& $(0.00)$ & $(0.00)$ & $(0.00)$ & $(0.00)$ & $(0.00)$ & $(0.00)$ \\
industry & control & control & control & control & control & control \\
year & control & control & control & control & control & control \\
\hline$R^{2}$ & 0.158 & 0.251 & 0.167 & 0.081 & 0.237 & 0.088 \\
adj. R2 & 0.147 & 0.241 & 0.156 & 0.072 & 0.230 & 0.078 \\
$N$ & 2768 & 2768 & 2768 & 3433 & 3433 & 3433 \\
\hline
\end{tabular}

Standard errors in parentheses $* \mathrm{p}<0.10, * * \mathrm{p}<0.05, * * * \mathrm{p}<0.01$

\subsubsection{Robustness test}

In order to verify the reliability of this conclusion, this paper carries out the robustness test in the following ways: (1) Referring to the method of Sheng Mingquan (2018), it is believed that with the senior executives getting older and entering the retirement age, they are faced with fewer opportunities for promotion, and their career expectations are gradually reduced, and 52 is a more obvious threshold, that is, the age of executives below 52 years old has more promotion opportunities and higher career expectation, while higher than 52 years old has less promotion opportunities and lower career expectation ${ }^{[14]}$. Therefore, this paper redefines the career expectation of executives, and uses the age of executives to measure the career expectations of executives. When the age of executives is less than or equal to 52 , the expected value of professional reputation is 1 , otherwise it is 0 ; (2) this paper reevaluates the measurement index of enterprise risk, and uses profit volatility (ROA) to measure enterprises according to $\mathrm{Yu}$ Minggui et al. (2013) [15]. Similarly, the standard deviation of the three-year ROA is used to measure the enterprise risk; (3) the research group considers that the decision-making power of Chinese enterprises is in the hands of the chairman of the board of directors, but it is executed by the general manager. The career expectation of the general manager may also affect the implementation effect of the decision-making, thus affecting the enterprise risk. Therefore, this paper increases the career of senior executives the general manager (CEO) level of robustness test. After the above robustness test, the conclusion is basically consistent with the previous paper. Therefore, this study believes that the higher the expectation of executives on their career, they will pay more attention to corporate governance and reduce the risk of enterprises.

\section{Conclusion}

Executive career expectations have a dual impact on corporate risk. On the one hand, executives with higher career expectations make diversified investments in order to improve the company's business performance, and over investment increases the enterprise's risk; on the other hand, through the implicit incentive of reputation effect, executives with higher career expectation, in order to maintain their own reputation in the industry and the company, at the same time, they pay more attention to the impact of their reputation damage. In order to reduce the occurrence of "reputation risk", they reduce the risk faced by enterprises by improving risk management and internal control. This paper uses the sample companies in Shanghai and Shenzhen stock markets to test it. The results show that executive career expectation can inhibit the occurrence of enterprise risk, and in the two mechanisms, reputation effect plays a leading role; and the sample companies are tested in groups, which shows that the executives of private enterprises pay more attention to their hard-established reputation, and then in order to maintain their reputation, they will pay more attention to the risk management and internal control of enterprises. This study provides a theoretical 
basis for enterprises to formulate "explicit" and "implicit" incentive contracts.

\section{Reference}

[1] M.G. Yu, W.G. Li, H.B. Pan, "Management Overconfidence and Enterprise Risk Taking," Journal of Financial research, vol. 01, pp. 149-163, 2013.

[2] R.J. Zhang, X.R. Li, N.H. Xu, "Does monetary compensation incentivize executives to take risks," Journal of Economic Theory and Business Management, vol. 08, pp. 84-100, 2013.

[3] X.L. Zhu, Y.J. Fang, "CEO power, executive team pay gap and corporate risk taking," Journal of Economic Survey, vol. 35, no. 01, pp. 100-7, 2018.

[4] J.L. Chen, L. Xiao, "Study on the relationship between overinvestment of female executives and enterprise value," Journal of Nanjing Audit University, vol. 12, no. 05, pp. 77-85, 2015.

[5] J.H. Ye, "The influence of key executives' military experience on enterprise risk taking," Journal of Finance Forum, vol. 22, no. 09, pp. 68-80, 2017.

[6] M.C. Jensen, W.H. Meckling, "Theory of the firm: Managerial behavior, agency costs and ownership structure," Journal of Social Science Electronic Publishing, vol. 3, no. 4, pp. 305-60, 1976.

[7] B.X. Zhao, F. Wang, Z. Li, "Empirical evidence on the career focus and investment efficiency of state-owned enterprises under the background of anti-corruption," Journal of Economic theory and economic management, vol. 12, pp. 78-93, 2015.

[8] H.S. Zeng, "Overinvestment leads to three major bubbles," Journal of China Finance, vol. 15, pp. 91-2, 2018.

[9] E.F. Fama, M.C. Jensen, “Agency Problems and Residual Claims," Journal of Law \& Economics, vol. 26, no. 2, pp. 327-49.

[10] H.S. Gao, J.M. Zhang, "The reputation and earnings management of independent directors in the process of marketization," Journal of China Certified Public Accountants, vol. 10, pp. 46-51, 2016.

[11] Q.Q. Xin, M.L. Huang, H.R. Yi, "An Analysis of the Relationship between the False Statements of Listed Companies and the Regulatory Penalty of Independent Directors," Journal of Management World, vol. 05, pp. 131-43+75+88, 2013.

[12] Z.H. Xie, "Internal control corporate governance risk management: relationship and integration," Journal of Accounting Research, vol. 10, pp. 37-45+95, 2007.

[13] W.G. Li, M.G. Yu, "Ownership nature, marketization process and enterprise risk-taking," China industrial economy, vol. 12, pp. 115-127N, 2012.

[14] M.Q. Sheng, S. Wang, Q. Bao, "Research on the relationship between career expectation and enterprise risk of senior managers in state-owned enterprises," Journal of management, vol. 15, no. 11, pp. 1647-1654, 2018

[15] M.G. Yu, W.G. Li, H.B. Pan, "Management Overconfidence and Enterprise Risk Taking," Journal of Financial Research, vol. 01, pp. 149-163, 2013. 